\title{
The Role of Social and Psychological Factors on Entrepreneurial Intention among Islamic College Students in Indonesia
}

\author{
Wahibur Rokhman, Forbis Ahamed
}

\begin{abstract}
A B S T R A C T
Objective: This study explores the influence of social and psychological factors on entrepreneurial behaviour among students studying at Islamic college of Kudus, Central Java, Indonesia.

Research Design \& Methods: Three hundred undergraduates that represent four faculties were selected using cluster-sampling technique for the investigation. Descriptive statistics and multiple regression technique were used to analyse data.

Findings: Results revealed that both social factors such as family background, education system and social status and psychological factors like need for achievement, propensity to risk and locus of control are quite prominent and significant indicators to become entrepreneurs.

Implications \& Recommendations: The study discovered that all the social attributes have impacts on entrepreneurship intention. University students who are properly trained can obviously play a leading role in this regard. This study is useful in identifying suitable students for any entrepreneurial activity in future. With the support of government, they can promote entrepreneurial culture in the country.
\end{abstract}

Contribution \& Value Added: Research on student entrepreneurship has intensified in some countries, but few have explored Islamic students in Indonesia.

Article type: research paper

Keywords: social factors; psychological factors; entrepreneurial intention JEL codes: A13, L26

Received: 17 December $2014 \quad$ Revised: 1 March $2015 \quad$ Accepted: 8 March 2015

\section{Suggested citation:}

Rokhman, W., \& Ahamed, F. (2015). The Role of Social and Psychological Factors on Entrepreneurial Intention among Islamic College Students in Indonesia. Entrepreneurial Business and Economics Review, 3(1): 29-42, DOI: http://dx.doi.org/10.15678/EBER.2015.030103. 


\section{INTRODUCTION}

Since the beginning of the 1980s, the interest in entrepreneurship has been growing around the world (Klofsten, 2000). Entrepreneurship is becoming a very relevant instrument to promote economic growth and development in different regional and national economies. The main factors contributing to this interest was the suffering of industrialized countries from economic recession, high unemployment rates and fluctuation in international trade cycles which most of these countries have not experienced before. This situation has tended to increase the attention paid to the potential role of entrepreneurs (Garavan \& O'Cinneide, 1994) as one of the possible solutions to the problems faced by most of the countries because the growth of entrepreneurial activities can help in creating jobs for the society and reducing the unemployment rate (Azhar, Javaid, Rehman \& Hyder, 2010).

The economic function of entrepreneurs allows us to highlight their important role as development agents. The entrepreneurs are responsible for the promotion of enterprises and businesses; they infuse dynamism in economic activity, manage organizational and technical changes and promote innovation and learning culture. Entrepreneurship is an attitude that reflects an individual's motivation and capacity to identify an opportunity and to pursue it, in order to produce new value or economic success (Ajzen, 1991).

However, social scientists have not still agreed on the determinants of the decision to become an entrepreneur. Early research in this regard has been focused on psychological characteristics and traits of individuals as antecedents of new venture creation and factors of venture success. Moreover, the most scholars mention educational systems, socio-cultural and economic factors as having a strong influence on the development of entrepreneurial behaviour of a given society.

Lerner and Pines (2011) emphasise five perspectives and the demographic variables, which refer to the individual level variables, and which are expected to be differentially associated with performance. These five perspectives are: (a) motivations and goals, (b) entrepreneurial socialization, (c) network affiliation, (d) human capital, and (e) environmental factors. Similarly, Haftendorn and Salzano (2003) stress sociocultural factors due to the fact that there are cultures that encourage entrepreneurial behaviour - curiosity, motivation by success, willingness to take risk, identification of opportunity and tolerance of uncertainty; tend to promote entrepreneurship development while some other cultures that are against these entrepreneurial behaviours are less likely to develop entrepreneurship.

Therefore, the main objective of this paper is to examine the factors that affect entrepreneurial intentions of undergraduate university students. Two factors this study is focused on were: social and psychological factors that influence on entrepreneurial intention among student at State Islamic College (STAIN) Kudus, Indonesia.

\section{LITERATURE REVIEW}

The term entrepreneurship originated from the French word "Entrepreneur". Entrepreneurs are also known as self-employed people. There is no fix definition for 
entrepreneurs since people from different field of study perceived and defined it differently. An economist defines an entrepreneur as one who brings resources, labour, materials, and other assets into combinations that make their value greater than before, and also one who introduces changes, innovations, and a new order. While to a psychologist, entrepreneur is typically driven by certain forces such as needs to obtain or attain something, to experiment and to accomplish targeted goal. To businessmen, an entrepreneur may be a threat, an aggressive competitor but may also be an ally, a source of supply, a customer, or someone who creates wealth for others as well as finds better ways to utilize resources, reduce waste, and provide jobs to others (Hisrich, Peters \& Shepherd, 2005).

Entrepreneurship is the dynamic process of creating incremental wealth. The wealth is created by individuals who assume major risks in terms of equity, time and career commitment or provide value for some products or services. The product or service may or may not be new or unique, but values must at least be infused by the entrepreneur by receiving and allocating the necessary skills and resources (Gumpert \& Stevenson, 1985). Entrepreneurship is the process by which individuals pursue opportunities regardless to the resources they currently control and also the art of turning ideas into a business (Barringer \& Ireland, 2010).

Almost all definition of entrepreneurship point out a kind of behaviour that include: (1) the initiative taking, (2) the organizing and reorganizing of social and economic mechanisms to turn resources and situations to practical account, and (3) the acceptance of risk or failure (Kirzner, 1979). According to Ajzen (1991), intention is the immediate antecedent of behaviour. He claimed that behaviour is not performed mindlessly but follows reasonably and consistently from the behaviour-relevant information and behaviour reinforced by rewarding events and weakened by punishing events.

So far, many studies on college students' intention to become entrepreneurs have been conducted in Indonesia. Christian (2000) studied Batak students' intention to be entrepreneurs and found that $65 \%$ of the respondent had intention to be entrepreneurs. Another study on Balinese students' intention showed that out of 105 respondents, $39.5 \%$ stated their intent to be an entrepreneur and 35\% more stated their desire to be entrepreneurs (Lie, 2004). Similar study done by Gerald (2006) on Javanese students' intention to be entrepreneurs found that out of 194 respondents, 30.4\% stated their intent to be entrepreneurs and $22 \%$ stated their desire to be entrepreneurs. However, no studies have been found that investigate entrepreneurial intention of college student with Islamic educational background.

Entrepreneurship education attempts to develop in the participants (students or trainees) intention to perform entrepreneurial behaviours, entrepreneurial knowledge and desirability of the entrepreneurial activity. There are various entrepreneurial education scopes and structures among higher education institutions in Malaysia. College students are trained as preparation to enter the business world according to their areas of study. However, whether they would be officers or entrepreneurs after graduation would be determined by their intent. An intention is an anticipated outcome guided by planned actions. The theory of planned behaviour emphasises links between attitudes and behaviours (Ajzen, 1991). Intentions predict deliberate behaviours because behaviour can be planned. Intention is assumed to take hold of emotional factors that 
influence behaviour and indicate one's effort to try to perform intentional behaviour. In the context of entrepreneurship, intension is identified as the important driver for establishing an organization (Katz \& Gartner, 1988) and as a predictor of new reliable enterprise (Krueger, Michael \& Casrud, 2000).

According to Birley \& Westhead (1993), the importance of entrepreneurial education is to help:

- to find solutions to problems or needs;

- to accept and respond to changes;

- to adjust to an increasingly global, competitive economy (aspects of tradition and the past may be left behind);

- to find new ways to solve social problems;

- to improve performance;

- to stimulate new business and the economy (new jobs and employment opportunities);

- to inspire and enhance opportunities for women, youth, elderly, minority groups;

- to move to an information society where the strategic resources are information, knowledge and creativity;

- to help workers shift to a service industry base from manufacturing and industrial base;

- to help reduce the number of failed business ventures.

Entrepreneurial intentions of university students in various cultural contexts indicated that the encouragement from university environment affects the entrepreneurial confidence of university students (Autio, Keeley, Klofsten, Parker \& Hay, 1997). Educational support through professional education in universities is an efficient way of obtaining necessary knowledge about entrepreneurship. This is supported by the study done by Wang and Wong (2004) who pointed out that those entrepreneurial dreams of many students are hindered by inadequate preparation of the academic institution.

The school and education system also play a critical role in identifying and shaping entrepreneurial traits (Ibrahim \& Soufani, 2002). Other studies have pointed out that entrepreneurship education, especially education that provides technological training is crucial to enhance entrepreneurs' innovation skills in an increasingly challenging environment (Galloway \& Brown, 2002; Garavan \& O'Cinneide, 1994).

Nevertheless, social scientists have not still agreed on the determinants of the decision to become an entrepreneur. Early research in this regard has been focused on psychological characteristics and traits of individuals as antecedents of new venture creation and pertaining factors (McClelland, 1961), risk taking propensity (Brockhaus, 1982), locus of control (Sexton \& Bowman, 1983), tolerance for ambiguity (Teoh \& Foo, 1997), etc. On the basis of previous studies explained above, one should conclude that the area of this study covers demographic profiles, attitudinal and behavioural factors, and how these influence the intentions of students to become entrepreneurs.

Further studies may be needed to justify that some structural change in the educational system is needed to promote the entrepreneurial spirit, desire and intention among the graduates due the following reasons (Baharu, 1994): 
- entrepreneurial training is lacking in the early education;

- most of the courses available are preparing students or graduates to be a knowledgeable employee instead of being an employer;

- the career education is not effective in shaping more entrepreneurs and to expose them to the business opportunities in making self-employment a career choice;

- the educational programs and trainings provided shall help to develop certain characteristics of entrepreneurship besides the knowledge and technical know-how for the business venture;

- an effective and flexible teaching program, appropriate teaching materials, sufficient research and reference materials shall be made available in the entrepreneurial education;

- certain policy framework is needed for implementing entrepreneurship education at national level, to improve the quality and effectiveness of the program, to open up such education and training to all and to make those programs easily accessible.

Wang \& Wong (2004) examined the entrepreneurial interest in Singapore and they determined the inadequate knowledge and perceived risk as significant indicators. Bhandari (2006) found that luck and ability to lead other people were significant variables for entrepreneurial intention among Indian university students. Gürol and Atsan (2006) investigated the entrepreneurial characteristics among fourth year students only from two Turkish universities and their analysis results exhibited that students who had higher risk taking propensity, internal locus of control, higher need for achievement and innovativeness were more entrepreneurially inclined students. Lee and Tsang (2001) suggested that customized approaches based on unique cultural context were needed for effective entrepreneurship education.

\section{MATERIAL AND METHODS}

\section{Hypotheses}

\section{Social Factors}

Some previous research has identified that although many of the students desire to run their own businesses, their dreams are hindered by inadequate preparation. Knowledge is insufficient for such kind of decision. Noel (1998) found that entrepreneurship education is strongly related to entrepreneurial intention, with entrepreneurship majors expressing higher intentions to start their own businesses. In this regard, another important factor, which has often discussed, is family's business background. Selfemployed parents affect the entrepreneurial interest as well as the career choice of their children. Scott and Twomey (1988) reported that students whose parents owned a small business demonstrated the highest preference for self-employment and the lowest for employment in a large business.

Brown (1990) also observed a similar phenomenon in the UK when conducting a training program to assist undergraduates in starting their own business. He found that $38 \%$ of the pre-selected students (who were very much interested in starting own business) had fathers with their own businesses. On the other hand, Brenner, Pringle \& Greenhaus (1991) found the influence of parental role on entrepreneurship propensity of U.S. business school undergraduates was insignificant. Ghazali, Ghosh \& Tay (1995) 
reported a similar observation on the self-employment choice of graduates in Singapore. The most detailed analysis so far is the study by Matthews and Moser (1995) that used longitudinal investigation for US graduates. They found the family background factor to be significant itself; prior exposure to entrepreneurship in practice, both direct and indirect through their family background in business, is significantly linked to their attitudes, norms, and perceived behavioural control regarding entrepreneurship. On the other hand, a prior research has found that in Singapore many self-employed persons are small store owners and may not be very wealthy. As such we developed a hypothesis to show the relationship between the social factors and the entrepreneurial intention.

H1: There is a

\section{Psychological Factors}

Personality traits have proven to be predictors of many aspects of entrepreneurship (Shaver \& Scott, 1991). Personality traits, known as trait theory, refer to personal characteristics of entrepreneurs. Personality traits have been divided into few categories: first, need for achievement, according to Sagie and Elizur (1999), McClelland's need for achievement theory highlighted that need for achievement is one of the strongest psychological factors influencing entrepreneurial behaviour. Individuals with high need for achievement have a strong desire to be successful and they are more likely to be entrepreneurs. McClelland (1961) suggested that individuals who possess a strong need for achievement are more likely to solve problems by themselves, set challenging goal, and strive to achieve it by their own efforts. Individuals with high need-forachievement will contribute more in entrepreneurial activity (Tong, Tong \& Loy, 2011). They are able to perform better in challenging tasks and discover innovative ways to enhance their performance (Littunen, 2000). From the result of Tong et al. (2011), need for achievement is the strongest predictor of entrepreneurial intention.

According to the trait approach one characteristic an entrepreneur should have is the ability of taking risk. Colton and Udell (1976) recommended that the risk-taking trait, along with creativity and flexibility, is a better indicator of the likelihood of starting a business than is achievement motivation. Studies generally support the notion that propensity to risk is predispositional, is not simply a situational variable and, subsequently, there is a strong evidence for a propensity for risk-taking (Jackson, Hourany \& Vidmar, 1972). Differently put, an entrepreneur must take risk to establish a business venture. Types of risk an entrepreneur faces are financial risk, management risk and personal risk (Gartner, 1990).

A large number of studies on qualitative aspects of entrepreneurs have focused on the psychological characteristics and personality traits, which differentiate successful entrepreneurs from unsuccessful entrepreneurs. Here we mainly narrowed the psychological factor into 'attitudes', 'believes', and 'goals' of individuals. Previous researches have demonstrated that individuals do consider risk, independence and income when evaluating alternative career options on the point of entrepreneurship. Further, they have found that the intention to be an entrepreneur is stronger for those with more positive attitudes to risk and the more positive their attitude to decisionmaking autonomy, the stronger is their stated intention to be an entrepreneur. 
Locus of control is a psychological characteristic that is related to the ability of individuals to control the events of life. Individuals with strong internal locus of control believe that they are able to control life's events while individuals with external locus of control believe that life's events are the result of external factors, such as chance, luck or fate (Hay, Kash \& Carpenter, 1990; Millet, 2005). Those individuals with a higher internal locus of control are deemed to be self-employed (Bönte \& Jarosch, 2011) and have high motivation to improve the efficiency of work (Göksel \& Aydintan, 2011) than those with strong external locus of control. The former have the ability to control the environment through their action and they are willing to take risks (Mueller \& Thomas, 2000). Gürol and Atsan (2006); Khan, Ahmed, Nawaz \& Ramzan (2011) found that with internal locus of control, the students will perform good attitude against entrepreneurial intention and high possibility to become an entrepreneur. Hence, it can be concluded that the higher the internal locus of control of undergraduates, the higher the entrepreneurial intentions.

Douglas and Shepherd (2002) have confirmed that those with a higher entrepreneurial intention are associated with a "more positive" attitude toward risk and independence. Thus, high entrepreneurial intention is found among those people who gain less disutility from risk and more utility or less disutility from independence. Also Douglas and Shepherd (2002) have further substantiated that the person with more positive attitude to interdependence would jump into self-employment more readily, since the availability of sufficiently remunerative opportunities is more likely to be forthcoming for that person. Conversely, the person with a less positive attitude to independence needs to await more remunerative self-employment opportunities, other factors being equal. As such we established a hypothesis to show the relationship between the psychological factors and the entrepreneurial intention. Figure 1 shows its graphical conceptualization.

There is a positive relationship between psychological factors and H2: entrepreneurial intention.

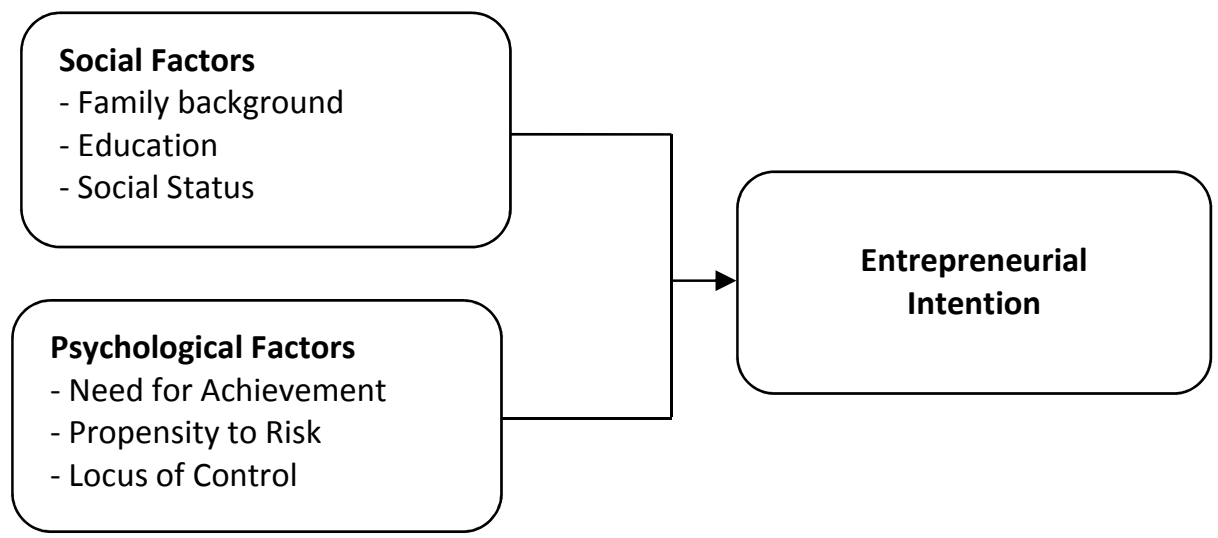

Figure 1. Conceptual Framework

Source: own study. 


\section{Research Methods}

This study was carried out through a survey method, with use of questionnaires. The population for this study consisted of all students at the undergraduate level registered during the academic year 2013-2014 at State Islamic College, Kudus, Indonesia. The sampling method employed for this study was cluster sampling which divided samples based on four faculties in this College. Data for the study was collected using a standard questionnaire. The questionnaire consisted of two parts: the first part consisted of questions on demographic profile of the respondents. The second part had 21 items questions covering: entrepreneurial intention (4), psychological factor (9) and social factors (8). The respondents were asked to state their agreement/disagreement on statements on a 5 -point Likert scale with ( $1=$ strongly disagree, $5=$ strongly agree).

\section{RESULTS AND DISCUSSION}

In this section, the data analysis is presented. There were 300 questionnaires collected from four different faculties in STAIN Kudus namely Islamic education, Islamic law, Islamic Theology, and Preaching and Islamic information. The questionnaires were coded for statistical analysis using the SPSS 14.0 to analyse profile of the respondents, descriptive statistics of the variables, and inter-correlations of the variables.

Table 1. Profile of respondents

\begin{tabular}{|l|r|r|}
\hline \multicolumn{1}{|c|}{ Demographic Variables } & Frequency & Percentage \\
\hline Gender & 126 & \\
Male & 174 & 42 \\
Female & & 58 \\
\hline Age & 78 & \\
$17-19$ & 201 & 26 \\
$20-23$ & 21 & 67 \\
$24-25$ & & 7 \\
\hline Faculty & 75 & \\
Islamic Education & 76 & 25 \\
Islamic Law & 75 & 25 \\
Islamic Theology & 74 & 25 \\
Preaching and Islamic Information & & 25 \\
\hline Monthly Income of Household Head (Million IDR) & 187 & \\
1-2 & 90 & 62 \\
2.1-5 & 23 & 30 \\
5- above & & 8 \\
\hline Occupation of Household Head & 103 & \\
Farmer & 110 & 34 \\
Entrepreneurs & 29 & 37 \\
Employee & 17 & 10 \\
Teacher & 17 & 6 \\
Government staff & 24 & 6 \\
Others & 300 & 7 \\
Total & & \\
\hline
\end{tabular}

Source: own study. 
Table 1 reveals that $42 \%$ (126) of the respondents were male, while 58\% (174) were female. This implies that more females than males were participating in the study. Majority (67\%) of the participants were $20-23$ years old as $26 \%$ participants were $17-19$ years of age, and $7 \%$ of the rest of participants were between $24-25$ years old (see Table 1 for the details profile's of respondents).

The table below (Table 2) explained the means (M), standard deviations (SD), and the correlation coefficients among the study variables. Among the factors, the mean values was counted to be the lowest in $(M=3.34, S D=.53)$ and the highest in $(M=3.90$, $\mathrm{SD}=.87)$ while it was observed $(M=3.79, S D=1.03)$. It is obvious from the table that all $r$ values range from 0.33 to 0.46 and the correlations were found to be statistically significant at $(p<0.01)$ level.

Table 2. Means, standard deviations, and correlations between variables

\begin{tabular}{|l|r|l|l|l|}
\hline \multicolumn{1}{|c|}{ Variable } & Mean & \multicolumn{1}{c|}{ SD } & \multicolumn{1}{|c|}{ EI } & \multicolumn{1}{c|}{ PF } \\
\hline 1. Entrepreneur Intention (EI) & 3.90 & 0.87 & 1.00 & \\
\hline 2. Psychological Factors (PF) & 3.34 & 0.53 & $0.355^{* *}$ & 1.00 \\
\hline 3. Social Factors (SF) & 3.79 & 1.03 & $0.460^{* *}$ & $0.337^{* *}$ \\
\hline
\end{tabular}

Notes: $* *=$ significant at $p<0.01$

Source: own study.

To address the purpose of the study, the proposed hypotheses were tested using regression analyses. The result of simple linear regression analyses are summarized in Table 3. As expected $(\mathrm{H} 1)$ the regression results revealed that social factor is a significant predictor of entrepreneur intention as hypothesized $\left(R^{2}=0.216, p<0.01\right)$. The finding also supported $\mathrm{H} 2$ which predicted a positive relationship between psychological factor and entrepreneur intention. The psychological factor scores explained about $34.6 \%$ of variation $(F=23.79, p<0.01)$ in entrepreneur intention perception.

Table 3. The result of regression analysis

\begin{tabular}{|c|c|c|c|}
\hline Independent Variables & \multicolumn{3}{|c|}{ Entrepreneur Intention } \\
\hline Dependent Variable & $\mathrm{R}^{2}$ & F change & $(\Omega)$ \\
\hline - Psychological Factor & .216 & $17.97^{* *}$ & $0.210^{* *}$ \\
- Social Factor & .346 & $23.79 * *$ & $0.246^{* *}$ \\
\hline
\end{tabular}

Note: ${ }^{* *} \mathrm{p}<0.01$

Source: own study.

\section{CONCLUSIONS}

The purpose of the study was to investigate the relationship between social factor and entrepreneurship intention and the relationship between psychological factor and entrepreneurship intention among Islamic college students in Kudus, Indonesia. The study hypothesized that there is a significant relationship between social factor and entrepreneurship intention. In addition, the study posited a relationship between psychological factor and entrepreneurship intention. In general, the results of the analysis provide empirical supports for these hypotheses.

The result obtained showed that psychological factors and social factors have a strong indication of entrepreneurial intention. This study was in line with the finding of 
McClelland (1961); Shaver and Scott (1991), and Sama-Ae (2009). These studies found that psychological characteristics of entrepreneurs have received particular attention all over the world. Psychological factor has attempted to characterize important variables such as personality, attitudes, demography, and behaviour as important measurement in the real entrepreneur practices (McClelland, 1961). Moreover, social factors have direct impact on many entrepreneurial activities including the intention to launch a new business, success in business, and enhance entrepreneurial set up Thus, these factors are important to determine the entrepreneurial characteristics among students and which characteristics might influence them to be entrepreneurs (Taramisi Sama-Ae, 2009). In conclusion, this study found that psychological factors such as familial background, personality trait and self-efficacy of the respondents are very connected with entrepreneurial intention. It is therefore, indispensable for counselling practitioners to make use of these variables while counselling.

Several implications could be gleaned from the outcome of this study. Prominent among these is the need for family support for improving entrepreneur intention among university students. Additionally, the study discovered that of all the social attributes such as need for achievement, propensity to risk and locus of control have significant impacts on entrepreneurship intention. Entrepreneurship has a significant position in the rapidly changing socioeconomic scenarios of the world. The present research might stimulate further research work in the field. The specially designed measuring instrument developed by the researchers could be helpful for future investigators. By taking into account the example of other developed countries, Indonesia could boost its economy through entrepreneurial promotion.

University students those who are properly trained can obviously play a leading role in this regard. This study is useful in identifying suitable students for any entrepreneurial activity in future. With the support of government, they can promote entrepreneurial culture in the country.

\section{REFERENCES}

Ajzen, I. (1991). The theory of planned behavior. Organisational Behavior and Human Decision Processes, 50(2), 179-211.

Azhar, A., Javaid, A., Rehman, M., \& Hyder, A. (2010). Entrepreneurial intention among business students in Pakistan. Journal of Business Systems, Governance and ethics, 5(2), 13-21.

Autio, E., Keeley, R.H., Klofsten, M., Parker, G.G.C., \& Hay, M. (2001). Entrepreneurial Intent among Students in Scandinavia and in the USA. Enterprise and Innovation Management Studies, 2(2), 145-160.

Baharu, K. (1994). Orientasi Sikap Keusahawanan Di Kalangan Pelajar Politeknik Malaysia.

Barringer, B.R., \& Ireland, R.D. (2010). Entrepreneurship: successfully launching new ventures (3rd Ed.). New Jersey: Pearson.

Bhandari, C. Narendra. (2006). Intention for Entrepreneurship among Students in India. Journal of Entrepreneurship, 15(2), 169-179.

Birley, S., \& Westhead, P. (1993). A comparison of new businesses established by 'novice' and 'habitual' founders in Great Britain. International Small Business Journal, 12(1), 38-60. 
Bönte, W., \& Jarosch, M. (2011). Gender Differences in Competitiveness, Risk Tolerance, and other Personality Traits: Do they contribute to the Gender Gap in Entrepreneurship? Paper presented at the Schumpeter School of Business and Economics, University of Wuppertal, Germany.

Brenner, O.C., Pringle, C.D., \& Greenhaus, J.H. (1991). Perceived fulfilment of organisational employment versus entrepreneurship: work values and career intentions of business college graduates. Journal of Small Business Management, 29(3), 62-74.

Brockhaus, R.H. (1982). Psychology of an Entrepreneur. In C.A. Kent, D.L. Sexton, \& K.H. Vesper (Eds.), Encyclopaedia of Entrepreneurship (pp. 39-57). Englewood Cliffs: Prentice-Hall.

Brown, R. (1990). Encouraging enterprise: Britain's Graduate Enterprise Program. Journal of Small Business Management 28 (4), 71-77.

Christian, M. (2000). Faktor-Faktor yang Mempengaruhi Intensi untuk Menjadi Wirausahawan Pada Mahasiswa Semester 6 ke Atas Beretnis Batak. Skripsi. Fakultas Psikologi Universitas Atma Jaya, Jakarta.

Colton, R., \& Udell, G., (1976). The national science foundation's innovation center-An experiment in training potential entrepreneurs and innovators. Journal of Small Business Management, 21(3), 11-20.

Douglas, E.J., \& Shepherd, D.A. (2002). Self-employment as a career choice: attitudes, entrepreneurial intentions, and utility maximization, Entrepreneurship Theory and Practice, 26(3), 81-90.

Galloway, L., \& Brown, W. (2002). Entrepreneurship education at university: a driver in the creation of high growth firms? Education Training, 44(8/9), 398-405.

Garavan, T.N., \& O'Cinneide, B. (1994). Entrepreneurship education and training programmes: A review and evaluation. Journal of European Industrial Training, 18(11), 13-22.

Gartner, W.B. (1990). What are we talking about when we talk about entrepreneurship? Journal of Business Venturing, 5(1), 15-28.

Gerald, M.T. (2006). Gambaran Intensi dan Sifat-sifat Kewirausahaan Mahasiswa Jawa. Skripsi. Fakultas Psikologi Universitas Atma Jaya, Jakarta.

Ghazali, A., Ghosh, B.C., \& Tay, R.S.T. (1995). The determinants of self-employment choice among university graduates in Singapore. International Journal of Management, 12(1), 26-35.

Gumpert D.E., \& Stevenson, H.H. (1985). The heart of entrepreneurship. Harvard Business Review, March, 85-94.

Göksel, M.A., \& Aydintan, M.B. (2011). Gender, business education, family background and personal traits; a multi-dimensional analysis of their affects on entrepreneurial propensity: findings from Turkey. International Journal of Business and Social Science, 2(13), 35-48.

Gürol, Y., \& Atsan, N. (2006). Entrepreneurial characteristics amongst university students. Education \& Training, 48(1), 25-38.

Haftendorn, K., \& Salzano, C. (2003). Facilitating youth entrepreneurship, part 1: an analysis of awareness and promotion programmes in formal and non-formal education programmers. Geneva: International Labor Office.

Hay, R.K., Kash, T.J., \& Carpenter, M.J. (1990). The role of locus of control in entrepreneurial development and success. Journal of Business \& Entrepreneurship, 2(2), 13-22.

Hisrich, R.D., Peters, M.P., \& Shepherd, D.A. (2005). Entrepreneurship, 6 Ed., New York: McGrawHill Irwin.

Ibrahim, A.B., \& Soufani, K. (2002). Entrepreneurship education and training in Canada: A critical assessment. Education and Training, 44(8), 421-430. 
Jackson, D.N., Hourany, L., \& Vidmar, N.J. (1972). A four-dimensional interpretation of risk-taking. Journal of Personality, 40(3), 483-501.

Katz, J., \& Gartner, W. (1988). Properties of emerging organizations. Academy of Management, 13(3), 429-441.

Khan, M.M., Ahmed, I., Nawaz, M.M., \& Ramzan, M. (2011). Impact of personality traits on entrepreneurial intentions of university students. Interdisciplinary Journal of Research in Business, 1(4), 51-57.

Kirzner, M. (1979). The role of entrepreneurship and marketing in established firms. Industrial Marketing Management, 17, 337-346.

Klofsten, M. (2000). Training entrepreneurship at universities: a Swedish case, Journal of European Industrial Training, 24(6), 337-344.

Krueger, N.F. Jr., Reilly, M.D., \& Carsrud, A.L. (2000). Competing model of entrepreneurial intentions. Journal of Business Venturing, 15(5/6), 411-432.

Lee, D.Y., \& Tsang, E.W.K. (2001). The effects of entrepreneurial personality, background and network activities on venture growth. Journal of Management Studies, 38(4), 583-602.

Lerner, M., \& Pines, A.M. (2011). Gender and culture in family business: a ten-nation study. International Journal of Cross Cultural Management, 11(2), 113-131.

Lie, J. (2004). Gambaran Intensi dan Sifat-sifat Keusahawanan Mahasisiwa Bali. Master's Thesis, Universitas Atmajaya, Jakarta.

Littunen, H. (2000). Entrepreneurship and the characteristics of the entrepreneurial personality. International Journal of Entrepreneurial Behavior \& Research, 6(6), 295-309.

Matthews, C.H., \& Moser, S.B. (1995). Family background and gender: Implications for interest in small firm ownership. Entrepreneurship and Regional Development, 7(4), 365-377.

McClelland, D.C. (1961). The Achieving Society. Princeton: Van Nostrand.

Millet, P. (2005). Locus of control and its relation to working life: Studies from the fields of vocational rehabilitation and small firms in Sweden. Doctoral Thesis, Luleå University of Technology Sweden.

Mueller, S.L., \& Thomas, A.S. (2000). Culture and entrepreneurial potential: a nine country study of locus of control and innovativeness. Journal of Business Venturing, 16(1), 51-75.

Ni, L.W., Ping, L.B., Ying, L.Y., Sern, N.H., \& Lih, W.J. (2012). Entrepreneurial Intention: A Study among Students of Higher Learning Institution. Unpublished Undergraduate Thesis, University Tunku Abdul Rahman.

Noel, T (1998). Effects of entrepreneurial education on intent to open a business: An exploratory study. Journal of Entrepreneurship Education, 5(1), 3-13.

Nor Aishah, B., \& Yufiza, M.Y. (2004). Demographics and personal characteristics of the urban Malaysian entrepreneurs: an ethnic comparison. Proceedings of the 3 International Conference on SMEs in a Global Economy, University Teknologi Mara, Kuala Lumpur, Malaysia, 6-7 July, 2004.

Sagie, A., \& Elizur, D. (1999). Achievement motive and entrepreneurial orientation: a structural analysis. Journal of Organizational Behavior, 20(2), 375-387.

Scott, M.G., \& Twomey, D.F. (1988). The long term supply of entrepreneurs: Students career aspirations in relation to entrepreneurship. Journal of Small Business Management, 26(4), 5-13. 
Sexton, D.L., \& Bowman, N.B. (1983). Comparative Entrepreneurship Characteristics of Students. In J. Hornaday, J. Timmons, \& K. Vesper (Eds.), Frontiers of Entrepreneurship Research (pp. 465-478). Wellesley, MA: Babson College.

Shaver, K.G., \& Scott, L.R. (1991). Person, process, choice: the psychology of new venture creation, Entrepreneurship Theory and Practice, 16(2), 23-45.

Sama-Ae, T. (2009). An Examination on the Entrepreneurial Intention among Thai Students at Universiti Utara Malaysia (UUM). Unpublished Thesis, University Utara Malaysia.

Teoh, H.Y., \& Foo, S.L. (1997). Moderating effects of tolerance for ambiguity and risk-taking propensity on the role conflict-perceived performance relationship: evidence from Singaporean entrepreneurs. Journal of Business Venturing, 12(1), 67-81.

Tong, X.F., Tong, D.Y.K., \& Loy, L.C. (2011). Factors influencing entrepreneurial intentions among university students. International Journal of Social Sciences and Humanity Studies, 3(1), 487-496.

Wang, C.K., \& Wong, P.K. (2004). Entrepreneurial interest of university students in Singapore. Technovation, 24, 163-172. 


\section{Authors}

The contribution share of authors is equal and amounted to $50 \%$ each of them.

\section{Wahibur Rokhman}

Wahibur Rokhman is a Senior Lecturer at Department of Islamic Economics in the Sekolah Tinggi Agama Islam Negeri (STAIN) of Kudus, Indonesia. He received his Master degree from Gadjah Mada University and his Ph.D. from International Islamic University Malaysia. His research interests include: entrepreneurship, leadership, Islamic work ethic and organizational Justice. He is actively writing papers. Several of his works has been published in local and international journals.

\section{Forbis Ahamed}

Forbis Ahamed is a Senior Lecturer/Assistant Professor at the Faculty of Business Management and Professional Studies, Management and Science University, Malaysia. He obtained his PhD in leadership and organizational management from International Islamic University, Malaysia. Prior to joining the programme, he had worked for 10 years as a Lecturer at the Department of Psychology, Yangon University. His research interests include leadership styles, HR development from social, psychological \& cross-cultural perspective, organizational trust and employee engagement.

Correspondence to:

Wahibur Rokhman, Ph.D.

State Islamic College (STAIN) of Kudus

Jl. Conge Po Box 51

Kudus, Central Java, Indonesia

wahibur@gmail.com

\section{Copyright and License}

This article is published under the terms of the Creative Commons Attribution - NonCommercial - NoDerivs (CC BY-NC-ND 3.0) License http://creativecommons.org/licenses/by-nc-nd/3.0/ 